\title{
THE CONNECTION OF PERFECTIONISM AND FLOW WITH ATHLETES OF A DIFFERENT PERFORMANCE LEVEL
}

\author{
Anida R. Fazlagić, Milena Belić \\ State University in Novi Pazar, Department of Philosophical Sciences, Psychology Study Program, Serbia
}

\begin{abstract}
Athletes often report on the experiences of absolute dedication and flow that represent an extraordinary experience and act motivatively. Motivation is a natural product of our essential desires and needs, and the flow as a mental state relieves us of fears of judgment, which can be a motivational component of the flow model. The aim of this research was to find out to what extent perfectionism and flow are present in a group of athletes, whether perfectionism and the flow experience are linked, and which socio-demographic variables they correlate with. The research involved 50 professional athletes with participation at all competitive levels, from local level competitions to world level competitions. The instruments applied are the Multidimensional scale of perfectionism, the Questionnaire of Flow, the Semi-Structured Interview and the Questionnaire on Socio-demographic Characteristics. Through interviews, we received data on situations and emotions during the flow experience, where close to $98 \%$ of the athletes stated that they were not aware of the flow experience during its occurrence, but they could retrospectively invoke that feeling which remained the greatest and lasting trophy of their success. Almost on all sub-scales of Multidimensional scale of perfectionism, athletes achieve higher results compared to the general population. The results of the research have shown that there is no correlation between the flow experience and perfectionism, except when it comes to the connection of the flow experience with concern due to errors and this relationship is negative.
\end{abstract}

Key words: PERFECTIONISM / FLOW /ATHLETS

\section{INTRODUCTION}

Perfectionism is usually defined as a tendency for infallibility in all aspects of life (Flett, Hewitt, 2002). Some authors consider that the perfectionism is a relationship that an individual makes with his environment, and the nature of that relationship depends on the type of support that serves to maintain a certain kind of perfectionist behavior. That's why they consider that perfectionism should be viewed more like a term that describes patterns of behaviour than as an immutable personality trait (Slade, Owens, 1998).

Not so long ago, in psychology, perfectionism was seen as a one-dimensional construct which could be a disturbing factor in all human functioning and achievement, but also a disturbing factor in the aspect of satisfaction with life and overall health (Beck et al., 1979; Accordino et al., 2000 Ashby, Rice, 2002). However, with recent research, many concepts of per- fectionism have been developed which have multi-dimensionality as a common thread (Frost et al., 1990; Flett end Hewitt, 2002; Bieling, Israeli, Antony, 2004). However, results of the research which studied perfectionism as a multi-dimensional concept have shown that perfectionism does not bring a priori to negative outcomes, but can also have a positive impact on human functioning and achievement. Accordingly, the so-called positive and negative perfectionism are distinguished (Hamachek, 1978; Stoeber, Otto, 2006; Fedewa, Burns, Gomez, 2005). Terry-Short, Owens, Slade and Dewey (1995), among others, suggest the theoretical basis for the difference between positive and negative perfectionism, the so-called $a$ dual process model of perfectionism. According to these authors, the difference can be explained in accordance with Skiner's behavioral perspective that emphasizes the function of a certain behavior. Accordingly, the differences between the positive and the negative aspects of perfectionism are not in the behavior itself, 
but rather result from different motivations in their basis. Positive perfectionism refers to cognitions and behaviors aimed at achieving high goals, in order to achieve positive consequences, and it is encouraged by positive support and the desire for success. Negative perfectionism refers to cognitions and behaviors aimed at achieving high goals in order to avoid negative consequences, and is encouraged by negative support and fear of failure, therefore is often accompanied by fear, too high standards and frustrations.

Frost et al. (1990) distinguishes the following dimensions of perfectionism: excessively high personal standards, concern about performance errors, the suspicion of the quality of personal performance, the perception of parental expectations and parental criticality, and the excessive need for precision, organization and order, resulting in the construction of Multidimensional Perfectionism Scale (Multidimensional Perfectionism Scale, MPS-F) (Frost et.al, 1990).

The author Czikszentmihalyi describes flow as a complete commitment to one activity. The state of the flow is accompanied by an extraordinary concentration, the focus of attention is only on a given activity, and the person experiences a feeling of happiness and pleasure at the same time (Csikszentmihalyi, 2006). There are several factors that stimulate the state of flow: clear goals of unambiguous feedback and the balance between capabilities and tasks. Ceja and Navaro (Ceja, Navaro, 2009) argue that there are other factors that can influence the occurrence of flow: the greater possibility that requests are experienced as challenges, and not as a threat, and a feeling of coherence and meaning. According to Baumann and Scheffer (Baumann, Scheffer, 2010), the predictive circumstance of experiencing flow is given to individuals with a motive for achieving the flow. The motive for achieving flow is derived from various actions that individuals have learned to apply in specific situations, and are made up of two motives: a motive to look for challenges and a motive to solve problems.

In flow, there are several dimensions that characterize or contribute to this feeling (Nakamura and Csikszentmihalyi, 2002). These factors are as follows: 1) A challenging activity that requires skills or a balance between opportunities and challenges; 2) State of mind and activity; 3 ) Loss of self awareness - the flow requires maximum concentration and focus on a particular activity; 4) Clear Goals - help to complete commitment to particular activity; 5) Concentration and focusing - it involves dealing with certain ac- tivities that at the given moments require complete commitment, which at the same time does not allow the thinking about anything else; 6) A sense of control over the situation - people do not enjoy being in control, but in the sense of achieving control in difficult situations. A feeling of flow is also the feeling that a certain skill is completely ruled. 7) A changed sense of time - the subjective sense of time during the flow does not look like a real, objectively measured time; 8) Feedback, a direct and immediate reaction to stimulation - success and failure are obvious in the activity, so that behavior can be adapted to the new situation in time; 9) Activity itself is rewarding - satisfaction arises from performing certain activities. It is about intrinsic motivation, which does not require any external rewards.

On the basis of everything that has been said about perfectionism and the flow experience, it is clear why these concepts are closely related to sports. Sports activities, especially those related to professional sports which involve competitive activities, at the same time involve high abilities, a tendency to be the best and an attempt to outperform any established personal or external standard. On the other hand, well trained, high intrinsic motivation and complete dedication are often the correlates of the flow experience and often present in sports.

Therefore athletes are constantly facing dilemmas because: (according to Bajraktarević, 2008):

- an athlete can (and should) be unique and unrepeatable, but at the same time he is expected and asked to be like everyone else;

- an athlete needs to prove as much as possible superiority over his opponent, but to respect him at the same time;

- an athlete should set his competitive aspirations very high and very real at the same time.

It is exactly internal conflicts that athletes have in trying to respond to demands during the achievement of competitive results that causes greater anxiety and the need for constant growth and development of cognitive, emotional and personality traits that can contribute to success in sports. Therefore, the aim of this paper is to examine whether perfectionism is present through its multidimensional constructs in athletes, whether the flow is related to sporting situations and in what connection the flow experience and perfectionism defined as a multi-dimensional construct are. 


\section{THE METHOD}

\section{Respondents}

The research involved 50 athletes of different performance categories. The sample consisted of 38 (76\%) male respondents and 12 (24\%) female respondents, the average age of $23(\mathrm{M}=22,80$ (16- 41); $\mathrm{N}=50$ )

The average length of the sports service is 12 years $(M=11.68, N=50)$. The largest number of respondents, $100 \%$ of them, participated in local level competitions, $98 \%$ participated in national level competitions, $94 \%$ of respondents participated in international level competitions, while $38 \%$ participated in the world level competitions $(\mathrm{N}=50)$. The survey was conducted in November and December 2013, on a sample from the South-West Serbia. The data were collected during home visits or visiting clubs of respondents.

\section{Instruments}

\section{Multidimensional Perfectionism Scale}

The multidimensional perfectionism scale (MPS-F; Frost et. 1995) consists of 35 claims that measure perfectionism through six dimensions. Dimension Personal Standards is conceived as very high personal standards and the overriding importance attached to these high standards in self-evaluation. Dimension Concerns about errors is conceived as negative reactions to errors, the tendency to interpret the error as equal to failures, and the tendency to believe that a person will lose respect of others after the failure. A tendency towards the belief that parents of some athletes set high goals and that they are overly critical comprise the dimension Parental Expectations, or Parental Objections. Dimension Suspicion in personal performances is described as a feeling of insecurity in personal actions or thinking, and as a tendency to feel that tasks are not satisfactorily completed. Emphasis on importance and preference of order and organization constitutes the last component of perfectionism, called Organization. The scale has satisfactory reliability, and the coefficient of internal coincidence ranges from 0.77 to 0.93 in our study $\alpha=0.81$. According to the obtained results, the subscales show satisfactory reliability: Concerns about errors - 0.85; Organization - 0.87; Parental expectations - 0.79; Personal standards - 0.79; Suspicion in personal performances - 0.77; Parental objections -0.60 . The respondent responds by evaluating the degree of agreement with individual items on the 5-degree Likert's type scale (from 1 - I completely agree to 5 - I completely disagree). The total score is calculated as the sum of the matching points with individual items on all subscales except for the subscale Organization. Items related to Organization are not taken into account when calculating the overall scale result due to the low correlations of that subscale with other subscales, as well as with the sum of all the items of perfectionism scale.

\section{The flow experience questionnaire}

Flow experience questionnaire authors Csikszentmihaly \& Csikszentmihaly, 1988, consists of 11 claims, but due to the specificity of the sample, we selected the six items we used in this study. In order to leave the space for supplementing the state of flow through a semi-structured interview, by adjusting the questionnaire we tended to increase the objectivity of the results. The reliability of the flow questionnaire restructured for this study was checked by the coefficient of internal coexistence, and the custom questionnaire has satisfactory reliability with $\alpha=0,891$. The respondent responds by evaluating the degree of agreement with individual items on the 5-degree Likert's type scale (from 1 - does not look like me to at all to 5 - very similar to me). The total result is equal to the sum of the values given by the respondent.

\section{Semi-structured interview}

In order to get a fuller picture of the respondents and their ability to reach the state of flow, we used a semi-structured interview. During the research, respondents reported on their own experiences, feelings and activities when performing.

\section{Questionnaire on sociodemographic features}

The questionnaire was designed for the research purposes. Through this questionnaire, we tried to get basic information about athletes such as the category of sport (individual or group), the number of participations in the competitions, the motives for dealing with sports and the years spent in sports. 


\section{RESULTS AND DISCUSSION}

\section{Qualitative processing of results}

The athletes who took part in this research show a certain tendency to achieve the flow experience through a total score on the scale of $22,54(\mathrm{M}=$ $22.54, \mathrm{SD}=3.42$ ). Starting from the assumption that the theoretical range of results on a scale is from 0 to 30 , the achieved result observed through the average value can indicate the inclination of athletes to experience the state of flow. We tested the results on the scale with a semi-structured interview.

During the interview, we tried to find out from the respondents whether they had experienced a state of flow. Since the flow is a state an individual is not aware of in the moment of experiencing, this experience can only be discussed when it is over and when we look at it from a certain time distance. Therefore, during the interview, we tried to find out how individuals describe this experience. Almost all of the interviewed athletes reported on the same feelings, thoughts, the conditions through which they passed and which they experienced during the flow. Furthermore, the flow is characterized by the state of focus and concentration. During the interview, most athletes reported on the visualization of winning, medals, goals scored as motivation factors to persevere in their efforts and achieve a sense of euphoria over the victory. Internal control locus and intrinsic motivation help when attaining a state of flow.

However, for the success achieved, besides the athlete, its environment and the support it has from others is significant. Table 1 gives a percentage view of social support, significance of others, which athletes evaluated in relation to their importance.
Table 1. Support sources for athletes

\begin{tabular}{lc}
\hline Support & $\begin{array}{c}\text { Involment } \\
\text { (\%) }\end{array}$ \\
\hline Parents & 55 \\
\hline Coach & 37 \\
\hline Friends & 5 \\
\hline Audience & 3 \\
\hline
\end{tabular}

During the interview, athletes reported that their success was the result of persistent and hard work, and that only genuine love for sports was a supporting factor and a condition for achieving a state of flow. Table 2 shows the factors of motivation for dealing with sports.

Table 2. Factors that affect motivation expressed in percentages

\begin{tabular}{lc}
\hline $\begin{array}{l}\text { Factors of motivation }{ }^{*}\left({ }^{*} \text { Answers }\right. \\
\text { to the question: "I'm dealing with } \\
\text { sports due to.." })\end{array}$ & Part (\%) \\
\hline Health & 6 \\
\hline Awards & 2 \\
\hline Friendships & 0 \\
\hline True love for sports & 92 \\
\hline
\end{tabular}

\section{Perfectionism and the flow experience}

We used descriptive statistics and correlation to examine the relationship between perfectionism and the state of flow. The results were processed in the SPSS 18.0 statistic program.

Table 3 shows the descriptive values of the results obtained on Perfectionism scale's subscales. According to our results, the total values of all subscales are increased relative to the standard values.

Table 3. Arithmetic mean of achieved results on sub-scales of Multidimensional Perfectionism Scale

\begin{tabular}{lccc}
\hline \multicolumn{1}{c}{ Sub-scales } & $\begin{array}{c}\text { Arithmetic mean } \\
\text { of the } \\
\text { author of the scale }\end{array}$ & $\begin{array}{c}\text { Arithmetic mean } \\
\text { on a sample of } \\
\text { athletes }\end{array}$ & $\begin{array}{c}\text { Standard } \\
\text { deviation }\end{array}$ \\
\hline Concern for error & 18,52 & 22,36 & 8,09 \\
\hline Organization & 21,97 & 27,12 & 2,88 \\
\hline Parental expectations & 11,71 & 15,64 & 4,35 \\
\hline Personal standards & 20,77 & 27,96 & 3,70 \\
\hline $\begin{array}{l}\text { Suspicion in personal } \\
\text { ability }\end{array}$ & 10,08 & 10,00 & 3,54 \\
\hline \begin{tabular}{l} 
Parental objections \\
\hline
\end{tabular} & 7,34 & 10,48 & 2,76 \\
\hline
\end{tabular}


The results of our research have shown that in almost all subscales of the MPS-F scale, our respondents have increased scores in relation to the arithmetic mean obtained by validating the scale.

On the scale Concerns for errors where concern due to errors is defined as negative reactions to errors, the tendency to interpret the error as equal to failures, and the tendency to believe that a person will lose respect of others after the failure, respondents have achieved a high score. Since the interpretation of the failure is equal to failure, athletes obviously have difficulty to accept the failure and mistakes they make.

On the subscale Parental expectations athletes also showed significantly higher scores than on the standard test results. A tendency towards the belief that parents of individuals set high goals and that they are overly critical comprise the dimension of $\mathrm{Pa}$ rental Expectations or Parental Objections. The literature often states that three elements are responsible for the success of an athlete: the abilities of the athlete, parents and the coach (Barjaktarević, 2008) but the personal capacity of an individual, investing in physical and tactical preparation, as well as developing motivation for achieving are also additional elements of success. According to the results of our research, a qualitative analysis showed that most athletes indicated that their parents and coach were their biggest support. However, we are often the witnesses of the indirect role of parents, namely, their overwhelming desire for success, possible dreams that did not come true or that they still have, lack of cooperation with the coach and, most importantly, the constant expectations for the best results from the athlete, they create pressure with the athlete (Rice, Ashby, Preusser; 1996). In the process of growing an athlete, the need for parents to be with him and to understand him is one of the basic needs that provides the child with security and stability, where every decision of the child is created in cooperation with parents who are sufficiently involved in the situation. The involvement of parents in the training process is a crucial component that reduces the discrepancy between athletes, parents and coach, which reduces objections, and therefore expectations (Barjaktarević, 2008)

One of the most sensitive subscales for testing perfectionism is the subscale Personal Standards. According to Greblo (Greblo, 2012), advocating the idea that a multi-dimensional approach to the study of perfectionism is necessary (Hewitt et al 2003) he refers to early theorists who reported on the importance of the interpersonal aspect of perfectionism (Hamachek, 1978), and emphasizes that self-evaluation of perfectionists, above all, depends on the perception of the level of acceptance by significant others, and not exclusively about (un)achievement of high standards of achievement. In addition to this, perfectionists often require others to achieve high goals, which can also determine the characteristics of their psychosocial adaptation (Habke, Flynn, 2002). Generally speaking, athletes with high personal standards tend to re-evaluate the goals achieved they often declare as insufficient and easily achievable goals, which increases the risk of developing various difficulties.

However, what is particularly relevant to our sample is that there is no doubt in personal ability. Dimension Suspicion in personal performances is described as a feeling of insecurity in personal actions or thinking, as well as a tendency to feel that tasks are not satisfactorily completed. Obviously, engaging in sports activities contributes to self-confidence (Barjaktavević, 2008).

The correlation between perfectionism and the state of flow was also examined. The results are shown in Table 4.

Table 4. Correlation of the subscales of multi-dimensional perfectionism scale with a flow experience

\begin{tabular}{|c|c|}
\hline Sub-scale & $\begin{array}{l}F \quad 1 \quad \text { o } \\
\text { experience }\end{array}$ \\
\hline 1.Concern for errors &,$- 152^{\star \star}$ \\
\hline 2. Organization &, $108^{*}$ \\
\hline 3.Parental expectations & ,096 \\
\hline 4.Personal standards & ,059 \\
\hline 5. Suspicion in personal performance & 013 \\
\hline 6. Parental objections &, 013 \\
\hline
\end{tabular}

Generally, the results indicate a very weak linkage of the flow experience with perfectionism. When it comes to certain subscales, statistically significant correlations are missing. Statistically significant, but low, negative correlation of the Flow experience with the Concern about errors subscale was obtained. The flow experience implies a certain spontaneity, seizing the moment (to which the etymological significance of the word implies as well) (Nakamura and Csikszentmihalyi, 2002), while Concern about errors implies a desire for perfection filled with fear of possible 
mistakes, which leaves no space to any kind of relaxation. The flow experience is in a positive statistically significant connection with Organization. The correlation obtained is low, but it suggests that a certain measure of order, work and control over oneself and their own time is probably one of the correlates of a superior experience.

The flow experience of the athlete can act motivating and therefore needs to be nurtured and encouraged. It would be important to suggest coaches and sports workers that the excitement of the flow experience through frequent praise, patience, meeting the needs of athletes, is important for the formation of intricative motivation. Intricative motivation has long-term effects on the formation of an athlete's personality, and spontaneously on the success of the athlete himself as well.

\section{CONCLUSION}

Although there is a tendency to observe perfectionism as an aggravating factor for athletes, we must accept that the inclination to perfectionism has good sides, especially if we take into account its adaptive forms. The possibility to develop adaptive perfectionism is characteristic for athletes who strive for perfection, but only for personal reasons and intrinsic motives. Our sample showed that the true motive that drives them in sports is true love for sports. However, it is obvious that we must consider the pressure of parents and significant others as a significant factor. Striving for infallibility contributes to achieving top results, but does not provide a supreme experiences that are invaluable prize and motivating factor by themselves.

\section{Notes:}

This work was created within the 179002 Project funded by the Ministry of Education, Science and Technological Development Republic of Serbia.

8. Csikszentmihalyi, M. (1990). Flow: The Psychology of Optimal Experience. New York: Harper and Row.

9. Fedewa, B. A., Burns, L. R., Gomez, A.A. (2005). Positive and negative perfectionism and the shame/ guilt distinction: adaptive and maladaptive characteristics. Personality and Individual Differences, 38 (7), 1609-1619.

10. Flett, G.L., Hewitt, P.L. (2002). Perfectionism and maladjustment: An overview of theoretical, definitional, and treatment issues. U: G.L. Flett i P.L. Hewitt (Ur.), Perfectionism: Theory, research, and treatment (str. 5-31). Washington, DC: APA.

11. Frost, R. O., Heimberg, R. G., Holt, C. S., Mattia, J. I., Neuberg A. L. (1990). The dimensions of perfectionism. Cognitive Therapy and Research, 14, 449-468.

12. Greblo, Z. (2012). Šta se skriva iza pojma "perfekcionizam". Povijest proučavanja i pregled različitih konceptualizacija perfekcionizma. [What lies behind the notion of "perfectionism." History of study and review of various conceptions of perfectionism. In Croatian]. Psihologijske teme, 21, (1), 195-212.

13. Habke, A.M., Flynn, C.A. (2002). Interpersonal aspects of trait perfectionism. U: G.L. Flett, P.L. 
Hewitt (Ur.), Perfectionism: Theory, research, and treatment (str. 151-180). Washington, DC: APA.

14. Hamachek, D.E. (1978). Psychodynamics of normal and neurotic perfectionism. Psychology, 15, 27-33.

15. Hewitt, P. L., Flett, G. L. (1991). Perfectionism in the Self and Social Contexts: Conceptualization, Assessment, and Association With Psychopathology. Journal of Personality and Social Psychology, $60,(3), 456-470$.

16. Nakamura, J., Csikszentmihalyi, M. (2002). The concept of flow. In C. R. Snyder \& S. J. Lopez (Eds.), Handbook of positive psychology (pp. 89105). Oxford, UK: Oxford University Press.
17. Rice, K. G., Ashby, J. S., Preusser, K. (1996). Perfectionism, Relationships with Parents, and Self-Esteem. Individual Psychology, 52, (3), 246-260.

18. Slade, P. D., Owens, R. G. (1998). A dual process model of perfectionism based on reinforcement theory. Behavior Modification, 22, (3), 372-391.

19. Stoeber, J., Otto, K. (2006). Positive Conceptions of Perfectionism: Approaches, Evidence, Challenges. Personalitiy and Social Psychology Review, 10, (4), 295-319.

20. Terry-Short, L.A., Owens, R.G., Slade, P.D. Dewey, M.E. (1995). Positive and negative perfectionism. Personality and Individual Differences, 18, (5), 663-668.

\title{
VERBINDUNG ZWISCHEN PERFEKTIONISMUS UND DEM ERLEBNIS VON ERGRIFFENHEIT BEI SPORTLERN VON UNTERSCHIEDLICHER ERFOLGSEBENE
}

\begin{abstract}
Zusammenfassung:
Sportler berichten häufig von Erlebnissen absoluter Hingabe und Ergriffenheit, die eine außerordentliche Erfahrung darstellen und einen motivierenden Einfluss ausüben. Motivation ist ein natürliches Produkt unserer essentiellen Wünsche und Bedürfnisse, Ergriffenheit als mentaler Zustand befreit uns von der Angst vor Einschätzung, was eine Motivationskomponente im Ergriffenheitsmodell sein kann. Ziel dieser Untersuchung war es, festzulegen, in welchem Maße Perfektionismus und Ergriffenheit bei Sportlergruppen vertreten sind, ob sie untereinander verbunden sind und, wenn dies der Fall ist, mit welchen soziodemografischen Variablen sie korrelieren. An der Studie nahmen 50 Sportler aus allen Wettbewerbsebenen teil - von Wettbewerben auf lokaler Ebene bis zu Wettbewerben auf internationaler Ebene. Als Instrumente wurden die Multidimensionale Perfektionismus-Skala, ein Fragenbogen über Ergriffenheit, das halbstruktuierte Interview und ein Fragebogen über soziodemografische Merkmale angewendet. Mit Hilfe des Interviews wurden Informationen über Zustände und Emotionen während eines Erlebnisses der Ergriffenheit erfragt, wo 98\% der befragten Sportler aussagten, dass sie sich des Erlebnisses der Ergriffenheit im gegebenen Moment nicht bewusst sind, aber retrospektiv dieses Gefühl zurückrufen können, das für sie die größte und dauerhafteste Trophäe ihres Erfolgs darstellt. Sportler erzielen auf fast allen Ebenen der Multidimensionalen Perfektionismus-Skala Ergebnisse, die in Bezug auf die allgemeine Bevölkerung höher liegen. Ergebnisse der Untersuchung haben gezeigt, dass es keine Verbindung zwischen dem Erlebnis der Ergriffenheit und Perfektionismus gibt, außer wenn es sich um die Verbindung zwischen dem Erlebenis von Ergriffenheit und Besorgtheit wegen Fehlern handelt. In diesem Fall ist die Verbindung negativ.
\end{abstract}

Schlüsselwörter: PERFEKTIONISMUS / ERGRIFFENHEIT / SPORTLER

Received: 03. 05. 2017

Accepted: 11. 12. 2017. 


\title{
ПОВЕЗАНОСТ ПЕРФЕКЦИОНИЗМА И ДОЖИВЉАЈА ПОНЕСЕНОСТИ КОД СПОРТИСТА РАЗЛИЧИТОГ НИВОА УСПЕШНОСТИ
}

\author{
Анида Р. Фазлагић, Милена Белић \\ Државни универзитет у Новом Пазару, Департман за филозофске науке, Студијски програм Психологија, Србија
}

\begin{abstract}
Сажетак
Спортисти неретко извештавају о доживљајима апсолутне посвећености и понесености који представљају изузетно искуство и делују мотивационо. Мотивација је природни продукт наших суштинских жеља и потреба, а понесеност као ментлано стање ослобађа нас страхова од процене, што може бити мотивациона компонента модела понесености. Циљ овог истраживања био је да се сазнаа у којој мери су перфекционизам и понесеност заступљени код групе спортиста, да ли су перфекционизам и доживљај понесености повезани и са којим социодемографским варијаблама корелирају. У истраживању је учествовало 50 спортиста са учешћем на свим такмичарским нивоима, од локалног до светског нивоа. Примењени инструменти су: мултидимензионална скала перфекционизма, упитник понесености, полуструктурирани интервју и упитник о социодемографским обележјима. Путем интервјуа добијени су подаци о стањима и емоцијама током доживљаја понесености, где је близу 98\% испитаних спортиста изјавило да доживљаја понесености нису свесни током његовог дешавања, али да ретроспективно могу призвати ово осећање које остаје највећи и трајни трофеј њиховог успеха. Спортисти скоро на свим субскалама мултидимензионалне скале перфекционизма постижу резултате који су већи у односу на општу популацију. Резултати истраживања су показали да нема повезаности између доживљаја понесености и перфекционизма, изузев када су у питању везе доживљаја понесености са забринутошћу због грешака и та веза је негативна.
\end{abstract}

Кључне речи: ПЕРФЕКЦИОНИЗАМ / ПОНЕСЕНОСТ / СПОРТИСТИ

\section{УВОД}

Најчешће се перфекционизам дефинише као тежња за непогрешивошћу у свим аспектима живота (Flett, Hewitt, 2002). Поједини аутори сматрају да је перфекционизам веза коју појединац остварује са својом околином, а врста те везе зависи од типа поткрепљења које служи одржавању одређене врсте перфекционистичког понашања. Зठог тога сматрају да на перфекционизам треба гледати више као на појам који описује обрасце понашања, него као на неку непромењиву особину личности (Slade, Owens, 1998).

Не тако давно, у психологији се перфекционизам посматрао као једнодимензионални конструкт који може бити ометајући фактор у целокупном људском функционисању и постигнућу, али ометајући фактор и у аспекту задовољства животом и целокупног здравља (Beck et. al., 1979; Accordino et. al; 2000; Ashby, Rice; 2002). Међутим, са новијим истраживањима развијају се бројне концепције перфекционизма које као заједничку нит имају вишедимензионалност (Frost et.al., 1990; Flett i Hewitt, 2002; Bieling, Israeli, Antony, 2004). Резултати истраживања која су перфекционизам истраживали као вишедимензионални концепт, показују да перфекционизам не доводи априори до негативних исхода, већ може имати и позитиван утицај на људско функционисање и постигнуће. У складу са тим, разликује се тзв. позитивни и негативни перфекционизам (Hamachek, 1978; Stoeber, Otto, 2006; Fedewa, Burns, Gomez, 2005). Тери-Шорт и сарадници (Terry-Short et al, 1995), између осталих, предлажу теоријску основу ра- 
злике између позитивног и негативног перфекционизма, такозвани gвойроцесни моgел иеерфекционизм. Према овим ауторима, разлика се најбоље може објаснити у складу са Скинеровом бихејвиористичком перспективом која наглашава функцију коју одређено понашање има. У складу са тим, разлике између позитивног и негативног аспекта перфекционизма се не налазе у самом понашању већ произлазе из различите мотивације у њиховој основи. Позитиивни иеербекционизам се односи на когниције и понашања која су усмерена према достизању високих циљева, како би се постигле позитивне последице, а подстакнут је позитивним поткрепљењем и жељом за успехом. Неїайивни иеерфекционизам се односи на когниције и понашања усмерена ка постизању високих циљева како би се избегле негативне последице, а подстакнута је негативним поткрепљењем и страхом од неуспеха, те га често прате страх, превисоки стандарди и фрустрације.

Фрост и сарадници (1990) издвајају следеће димензије перфекционизма: ирретерано високи тични стианgарgи, забринуйости збоі їрешака у извођеюу, сумюа у квалитетет личноі извођења, иерриейција родитетьских очекивағьа и родииельска

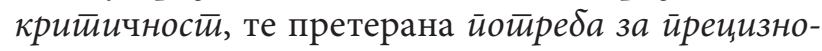
wћy, оріанизацијом и реgом, што је резултирало „конструкцијом“ мултидимензионалне скале перфекционизма (Multidimensional Perfectionism Scale, MPS-F) (Frost et.al, 1990).

Аутор Чиксентмихаљ понесеност описује као потпуну преданост једној активности. Праћена је изузетном концентрацијом, фокус пажње је само на датој активности, а особа истовремено доживљава осећање среће и задовољства (Csikszentmihalyi, 2006). У нашем језику не постоји адекватна реч која би заменила одомаћену употребу flow-a - ове енглеске речи. Буквални превод на наш језик значио би „струјање, или ток“, што је у складу са првим описима осећања понесености по којима је овај концепт и добио име. Постоји неколико чиниоца који подстичу стање понесености: јасни циљеви недвосмислене повратне информације и баланс између способности и задатка. Сеја и Наваро (Ceja, Navaro, 2009) тврде да постоје и други фактори који могу утицати на појаву понесености: што већа могућност да се захтеви доживе као изазови, а не као претња, те осећање кохерентности и смисла. Према Бауману и Шеферу (Baumann,Scheffer, 2010) предиктивну околност да доживе понесеност имају појединци код којих је изражен мотив за постигнућем понесености. Мотив за постигнућем понесености је изведен из различитих акција које су појединци научили да примењују у специфичним ситуацијама, и чине га два мотива: мотиив gа се тираже изазови и мотиив gа се решавају йроблеми.

Код понесености постоји неколико димензија које карактеришу или доприносе овом осећају (Nakamura i Csikszentmihalyi, 2002). Ти фактори су следећи: 1) изазовна активност која захтева вештине или равнотежа између могућности и изазова; 2) стање свести и активности, 3) губитак свести о себи - понесеност захтева максимум концентрације и фокусираност само на одређену активност; 4) јасни циљеви - помажу потпуном предавању одређеној активности; 5) концентрација и фокусирање - подразумева бављење одређеним активностима које у датим тренуцима захтевају потпуну посвећеност, које истовремено не допуштају размишљање о било чему другом; 6) осећај контроле над ситуацијом - људи не уживају у томе да имају контролу, већ у осећају постизања контроле у тешким ситуацијама. Осећај понесености подразумева и осећање да се одређеном вештином у потпуности влада. 7) измењен осећај за време - субјективни осећај времена током понесености не наликује реалном, објективно измереном времену; 8) повратне информације, односно, директна и тренутна реакција на стимулациjу - успех и неуспех су очигледни код активности, тако да се понашање може на време прилагодити новонасталој ситуацији; 9) активност је сама по себи награђујућа - задовољство проистиче из обављања одређене активности. Реч је о интризичној мотивацији, која не захтева никакве спољашње награде.

На основу свега што је досад речено о перфекционизму и доживљају понесености, јасно је зашто су ови концепти блиско повезани са бављењем спортом. Спортске активности, посебно оне које се тичу професионалног бављења спортом и које подразумевају такмичарске активности, у исто време подразумевају високе способности, тежњу да се буде најбољи и покушај да се надмаши сваки постављени лични или спољни стандард. С друге стране, савршена утренираност, висока интризичка мотивација и потпуна преданост, често су корелати доживљаја понесености и често присутни у спорту. 
Стога су спортисти стално пред дилемама јер (према Барјактаревић, 2008):

- спортиста може и (треба) да буде јединствен и непоновљив, али се од њега истовремено очекује и тражи да буде као и сви остали;

- спортиста треба да докаже што је више могуће већу надмоћност у односу на противника, али да га истовремено и уважава;

- спортиста треба да постави своје такмичарске аспирације истовремено и веома високо и веома реално.

Управо унутрашњи сукоби које спортисти имају у покушају да одговоре захтевима током остваривања такмичарских резултата, узрокују и већу анксиозност и потребу за сталним растом и развојем когнитивних, емоционалних и особина личности које могу допринети успеху у спорту. Стога је циљ овог рада испитивање да ли је перфекционизам присутан кроз своје вишедимензионалне конструкте код спортиста, да ли је доживљај понесености повезан са ситуацијама у вези са спортом и у каквој су вези доживљај понесености и перфекционизам дефинисани као вишедимензионални конструкти.

\section{МЕТОД}

\section{Испитаници}

У истраживању је учествовало 50 спортиста, различитих категорија успешности. Узорак је чинило 38 (76\%) мушкараца и 12 (24\%) жена, просечне старости 23 године (M=22,80 (16-41); $\mathrm{N}=50)$.

Просечна дужина спортског стажа је 12 година $(\mathrm{M}=11,68, \mathrm{~N}=50)$. Највећи број испитаника њих 100\% учествовало је на такмичењима локалног нивоа, 98\% учествовало је на такмичењима државног нивоа, 94\% испитаника учествовало је такмичењима међународног нивоа, док је $38 \%$ учествовало на такмичењима светског нивоа $(\mathrm{N}=50)$. Истраживање је спроведено током новембра и децембра 2013. године, на узорку са подручја југозападне Србије. Подаци су прикупљани током кућних посета или посете клубовима испитаника.

\section{Инструменти}

Мулииияимензионална скала иеррфекиионизма

Мултидимензионална скала перфекционизма (MPS-F; Frost i sur.1990) састоји се од 35 тврдњи које мере перфекционизам кроз шест димензија.

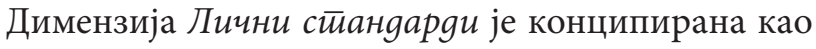
врло високи лични стандарди и претерана важност која се придаје тим високим стандардима

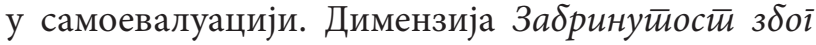
ірешака је конципирана као негативна реакције на грешке, тенденција ка интерпретацији грешка као једнаких неуспеху, и тенденција веровању да ће особа изгубити поштовање других након неуспеха. Тенденција ка веровању да родитељи неких спортиста постављају високе циљеве и да су претерано критични сачињавају димензију Роgитеельска очекиваґа, односно Родииельска йриїовараюа. Димензија Сумға у тична извођена описана је као осећај несигурности у личне акције или мишљење, и као тенденција осећању да задаци нису задовољавајуће завршени. Нагласак на важности и преферирању реда и организације чини задњу компоненту перфекционизма, названу Организованост. Скала има задовољавајућу поузданост, а коефицијенти унутрашње коезинстенције се крећу од 0,77 до 0,93 у нашем истраживању $\alpha=0,81$. Према добијеним резултатима субскале показују задовољавајућу поузданост: Забринутост због грешака - 0,85; Организованост - 0,87; Родитељска очекивања - 0,79; Лични стандарди - 0,79; Сумња у лична извођења - 0,77; Родитељска приговарања - 0,60. Испитаник одговара тако што процењује степен слагања с појединим ајтемима на скали Ликертовог типа од пет степени (од 1потпуно се слажем до 5- потпуно се не слажем). Укупан резултат рачуна се као збир степена слагања са појединим ајтемима на свим субскалама, осим на субскали Организованост. Ајтеми који се односе на Организованост не узимају се у обзир приликом рачунања укупног резулата скале због ниских корелација те субскале са осталим субскалама, као и са самом сумом свих ајтема скале перфекционизам.

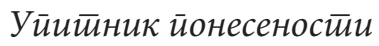

Упитник понесености (Flow experience questionnaire) аутора Csikszentmihaly \& Csikszentmihaly, 1988, састоји се од 11 тврдњи, али због специфичности узорка одабрали смо шест ајтема које смо користили у овом истраживању. Како бисмо оставили простор за допуну стања понесености кроз полуструктурирани интервју, прилагођавањем упитника настојали смо повећати објективност резултата. Поузданост Упитника понесености 
реструктурираног за ово истраживање проверавали смо коефицијентом унутрашње коезистенције, и прилагођени упитник има задовољавајућу поузданост уз $\alpha=0,891$. Испитаник одговара тако да процењује степен слагања с појединим ајтемима на скали Ликертовог типа од пет степени (од 1нимало не личи на мене до 5- врло слично мени). Укупан резултат једнак је збиру вредности које даје испитаник.

\section{Полустирукиичирани интеиервуу}

Како бисмо добили што потпунију слику о испитаницима и њиховој способности да достигну стање понесености, користили смо полуструктуирани интервју. Испитаници су током истраживања извештавали о властитим доживљајима, осећањима и активностима приликом извођења.

Уйийник о соииовемоірабским обележјима

Упитник је конструисан за потребе истраживања. Путем овог упитника настојали смо добити основне податке о спортистима као што су, категорија спорта (појединачни или групни), број учешћа на такмичењима, мотиве због којих се баве спортом и године проведене у спорту.

\section{РЕЗУЛТАТИ И ДИСКУСИЈА}

\section{Квалитативна обрада резултата}

Спортисти који су учестововали у овом истраживању показују извесну тенденцију ка постизању доживљаја понесености кроз укупан скор на скали од 22, $54(\mathrm{M}=22,54 ; \mathrm{CД}=3,42)$. Полазећи од претпоставке да је теоријски распон резултата на скали од 0-30, постигнути резултат посматран кроз просечну вредност може упућивати на склоност спортиста да доживе стање понесености. Постигнуте резултате на скали проверавали смо полуструктурираним интервјуом.

Током интервјуисања покушали смо да сазнамо од испитаника да ли су доживели стање понесености. Будући да је понесеност стање којег у моментима доживљавања појединац није свестан, о овом доживљају се једино може причати онда када прође и када га посматрамо са одређене временске дистанце. Стога смо током интервјуисања настојали да сазнамо како појединци описују тај доживљај. Скоро сви интервјуисани спортисти су извештавали о истим осећањима, мислима, стањима кроз која су пролазили и доживели током доживљаја понесености. Надаље, за понесеност је карактеристично стање фокусираности и концентрације. Већина спортиста је током интервјуа извештавала о визуализацији победе, медаље, постигнутог гола као факторима мотивације да истрају у својим настојањима и достигну осећај еуфорије због победе. Унутрашњи локус контроле и интризична мотивација помажу приликом достизања стања понесености.

Међутим, за постигнути успех, поред спортисте, значајна је његова околина и подршка коју има од стране значајних других. У табели 1 дат је процентуални приказ социјалне подршке, значајних других, који су спортисти вредновали у односу на њихову важност.

Табела 1. Извори подршке код спортиста

\begin{tabular}{lc}
\hline Подршка & $\begin{array}{c}\text { Учешће } \\
(\%)\end{array}$ \\
\hline Родитељи & 55 \\
\hline Тренер & 37 \\
\hline Пријатељи & 5 \\
\hline Публика & 3 \\
\hline
\end{tabular}

Током интервјуисања спортисти су извештавали да је њихов успех последица истрајног и напорног рада, а да је само истинска љубав према спорту подржавајући фактор и услов за постизање стања понесености. У табели 2 приказани су фактори мотивације за бављење спортом.

Табела 2. Фактори који утичу на мотивацију изражени у процентима

\begin{tabular}{lc}
\hline $\begin{array}{c}\text { Фактори мотивације }{ }^{*} \text { Одговори на } \\
\text { питање: „Спортом се бавим због ..“ }\end{array}$ & $\begin{array}{c}\text { Учешће } \\
(\%)\end{array}$ \\
\hline Здравље & 6 \\
\hline Награде, признања & 2 \\
\hline Дружење & 0 \\
\hline Истинска љубав према спорту & 92 \\
\hline
\end{tabular}

\section{Перфекционизам и доживљај понесености}

За испитивање односа перфекционизма и стања понесености користили смо дескриптивну статистику и корелацију. Резултати су обрађени у статистичком програму SPSS 18.0. У табели 3 приказане су дескриптивне вредности резултата добијених на субскалама Скале перфекционизма. Према резултатима укупне вредности свих субскала су повишене у односу на стандардне вредности. 
Табела 3. Аритметичеке средине постигнутих резултата на субскалама Мултидимензионалне скале перфекционизма

\begin{tabular}{lccc}
\hline \multicolumn{1}{c}{ Субскале } & $\begin{array}{c}\text { Аритметичка } \\
\text { средина } \\
\text { (аутор скале) }\end{array}$ & $\begin{array}{c}\text { Аритметичка } \\
\text { средина на узорку } \\
\text { спортиста }\end{array}$ & $\begin{array}{c}\text { Стандардна } \\
\text { девијација }\end{array}$ \\
\hline $\begin{array}{l}\text { Забринутост због } \\
\text { грешака }\end{array}$ & 18,52 & 22,36 & 8,09 \\
\hline Организованост & 21,97 & 27,12 & 2,88 \\
\hline Родитељска очекивања & 11,71 & 15,64 & 3,35 \\
\hline Лични стандарди & 20,77 & 27,96 & 3,54 \\
\hline $\begin{array}{l}\text { Сумња у властиту } \\
\text { способност }\end{array}$ & 10,08 & 10,00 & 2,76 \\
\hline $\begin{array}{l}\text { Родитељска } \\
\text { приговарања }\end{array}$ & 7,34 & 10,48 & \\
\hline
\end{tabular}

Резултати нашег истраживања су показали да на готово свим субскалама МПС-Ф скале наши испитаници имају повишене скорове у односу на аритметичку средину добијену валидацијом скале.

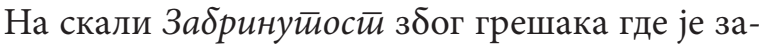
бринутост дефинисана као негативна реакције на грешке, тенденција ка интерпретацији грешка као једнаких неуспеху, и тенденција веровању да ће особа изгубити поштовање других након неуспеха, испитаници су постигли висок резултат. Будући да је изједначена интерпретација грешке са неуспехом, спортисти очигледно имају потешкоћа да прихвате неуспех и грешке које праве.

На субскали Роgииельска очекивања спортисти су такође показали значајно више скорове од стандардних резултата на тесту. Тенденција веровању да родитељи појединаца постављају високе циљеве и да су претерано критични, сачињавају димензију Родитељска очекивања, односно Родитељска приговарања.Често се у литератури наводи, како су за успех спортисте, битна три елемента: способности спортисте, родитељи и тренер (Барјактаревић, 2008), али су и лични капацитет појединца, улагање у физичку и тактичку припрему, као и развијање мотивације за постигнућем, додатни елементи успешности. Према резултатима нашег истраживања, квалитативна анализа је показала да је највећи број спортиста навео да су родитељи и тренер њихова највећа подршка. Међутим, неретко смо сведоци посредне улоге родитеља, тачније њихове претеране жеље за успехом, могућим неоствареним сновима које су имали или још увек имају, несарадњом са тренером и што је најважније сталним очекивањима најбољих резултата од спортисте, стварају „притисак“на спортисту (Rice,
Ashby, Preusser; 1996). У процесу одрастања једног спортисте потреба да родитељи буду уз њега и да га разумеју је једна од основних потреба која детету пружа сигурност и стабилност, где свака одлука детета настаје у сарадњи са родитељима који су довољно упућени у ситуацију. Укључивање родитеља у процес тренирања кључна је компонента која смањује дискрепанцу између спортисте, родитеља и тренера, чиме се смањују приговарања, а самим тим и очекивања (Барјактаревић, 2008)

Једна од најосетљивијих субскала за испитивање перфекционизма јесте субскала Лични сйанgарgи. Према Гребло (Гребло, 2012), заговарајући идеју да је вишедимензионални приступ у изучавању перфекционизма нужан (Hewitt et al 2003) се позивају на ране теоретичаре који су извештавали о важности интерперсоналнога аспекта перфекционизма (Hamachek, 1978), те истичу како самоевалуација перфекциониста пре свега зависи од перцепције степена прихватања од стране значајних других, а не искључиво о (не) остварењу високих стандарда постигнућа. Осим наведенога, перфекционисти често и од других захтевају остварење високих циљева, што такође може одредити обележја њихове психосоцијалне адаптације (Habke, Flynn, 2002). Генерално гледано, спортисти са високим личним стандардима склони су реевалуирању постигнутих циљева, које неретко проглашавају недовољним и лако достижним циљевима, чиме се повећава ризик за развој различитих тешкоћа.

Међутим оно што је посебно значајно за наш узорак јесте да нема сумње у властиту способност. Димензија Сумға у лична извођена описана је као осећај несигурности у личне акције или мишљење, 
и као тенденција осећању да задаци нису задовољавајуће завршени. Очигледно је да бављење спортским активностима доприноси самопоуздању (Барјактаревић, 2008).

Испитана је и корелација перфекционизма и стања понесености. Резултати су приказани у Табели 4 .

Табела 4. Корелација субскала мултидимензионалне скале перфекционизма са доживљајем понесености

\begin{tabular}{lc}
\hline Субскале & $\begin{array}{c}\text { Доживљај } \\
\text { понесености }\end{array}$ \\
\hline 1.Забринутост због грешака &,$- 152^{\star *}$ \\
\hline 2. Организованост &, $108^{\star}$ \\
\hline 3.Родитељска очекивања &, 096 \\
\hline 4.Лични стандарди &, 059 \\
\hline 5.Сумња у лично извођење &, 013 \\
\hline 6. Родитељска приговарања &, 013 \\
\hline${ }^{*} \mathrm{p}<0,05 ;{ }^{* *} \mathrm{p}<0,01$ &
\end{tabular}

Генерално, резултати указују на веома слабу повезаност доживљаја понесености са перфекционизмом. Када су у питању поједине субскале у потпуности изостају статистички значајне корелације. Добијена је статистички значајна, али ниска, негативна корелација Доживљаја понесености са субскалом Забринутост због грешака. Доживљај понесености подразумева извесну спонтаност, препуштању тренутку (на шта и етимолошко значење речи упућује) (Nakamura i Csikszentmihalyi, 2002), док Забринутост због грешака имплицира тежњу ка савршенству испуњену грчом страха због могућих грешки, што не оставља простора ни зна какву опуштеност. Доживљај понесености је у позитивној статистички значајној вези са Организованошћу. Добијена корелација је ниска, али упућује на претпоставку да

\section{ЛИТЕРАТУРА:}

1. Accordino, D. B., Accordino, M. P., Slaney, R. B. (2000). An investigation of perfectionism, mental health, achievement, and acheivement motivation in adolescents. Psychology in the Schools, 37, 535-545.

2. Ashby, J. S., Rice, K. G. (2002). Perfectionism, dysfunctional attitudes, and selfesteem:A structural equations analysis. Journal of Counseling and Development, 80, 197-203. извесна мера реда, рада и контроле над собом и сопственим временом је вероватно један од корелата врхунског доживљаја.

Доживљај понесености код спортисте може деловати мотивационо и стога га треба неговати и подстицати. Значајно би било тренерима и спортским радницима сугерисати да је побуђивање доживљаја понесености кроз честе похвале, стрпљење, излажење у сусрет потребама спортиста, значајано за формирање интризичне мотивације. Интризична мотивација има дугорочне ефекте на формирање личности једног спортисте, а спонтано и на успешност самог спортисте.

\section{ЗАКЉУЧАК}

Иако постоји тенденција да се перфекционизам посматра као отежавајући фактор код спортиста, морамо прихватити да склоност ка перфекционизму има и добрих страна, посебно ако узмемо у обзир његове адаптивне форме. Могућност за развој адаптивног перфекционизма имају спортисти који теже савршенству, али само из личних разлога и интризичних мотива. Наш узорак је показао да је основни мотив који их покреће у спорту истинска љубав према спорту. Међутим, очигледно је да морамо узети у обзир притисак родитеља и значајних других као значајан фактор. Тежња ка непогрешивошћу доприноси остварењу врхунских резултата, али не обезбеђује и врхунске доживљаје који су непроцењива награда и мотивишући фактор сами по себи.

\section{Напомена:}

Овај рад је настао у оквиру пројекта $\delta р .179002$ који финансира Министраство образовања, науке и технолошког развоја Републике Србије.

3. Барјактаревић, J. (2008). Психолоіија сӣорӣа: иееорија и емӣuрија. Сарајево: Арка прес.

4. Baumann, N., Scheffer, D. (2010). Seeking flow in the achievement domain: The achievement flow motive behind flow experience. Motivation and Emotion, 34, 122-134.

5. Beck, A.T, Rush, J., Shaw, B.F., Enery, G. (1979). Cognitive therapy of depression. New York: The Guilford Press. 
6. Bieling, P. J., Israeli, A. L., Antony, M. M. (2004). Is perfectionism good, bad, or both? Examining models of the perfectionism construct. Personality and Individual Differences, 36, 1373-1385.

7. Ceja, L., Navarro, J. (2009). Dynamics of flow: A nonlinear perspective. Journal of Happiness Studies, $10,665-684$.

8. Csikszentmihalyi, M. (1990). Flow: The Psychology of Optimal Experience. New York: Harper and Row.

9. Fedewa, B. A., Burns, L. R., Gomez, A.A. (2005). Positive and negative perfectionism and the shame/ guilt distinction: adaptive and maladaptive characteristics. Personality and Individual Differences, 38 (7), 1609-1619.

10. Flett, G.L., Hewitt, P.L. (2002). Perfectionism and maladjustment: An overview of theoretical, definitional, and treatment issues. U: G.L. Flett i P.L. Hewitt (Ur.), Perfectionism: Theory, research, and treatment (str. 5-31). Washington, DC: APA

11. Frost, R. O., Heimberg, R. G., Holt, C. S., Mattia, J. I., Neuberg A. L. (1990). The dimensions of perfectionism. Cognitive Therapy and Reasearch, 14, 449-468.

12. Гребло., 3. (2012). Шта се скрива иза појма “перфекционизам”. Повијест проучавања и преглед различитих концептуализација перфекционизма. Психолоіијске ииеме 21, (1), 195-212

13. Habke, A.M., Flynn, C.A. (2002). Interpersonal aspects of trait perfectionism. U: G.L. Flett, P.L.
Hewitt (Ur.), Perfectionism: Theory, research, and treatment (str. 151-180). Washington, DC: APA.

14. Hamachek, D.E. (1978). Psychodynamics of normal and neurotic perfectionism. Psychology, 15, 27-33.

15. Hewitt, P. L., Flett, G. L. (1991). Perfectionism in the Self and Social Contexts: Conceptualization, Assessment, and Association With Psychopathology. Journal of Personality and Social Psychology, 60, (3), 456-470.

16. Nakamura, J., Csikszentmihalyi, M. (2002). The concept of flow. In C. R. Snyder \& S. J. Lopez (Eds.), Handbook of positive psychology (pp. 89105). Oxford, UK: Oxford University Press.

17. Rice, K. G., Ashby, J. S., Preusser, K. (1996). Perfectionism, Relationships with Parents, and Self-Esteem. Individual Psychology, 52, (3), 246-260.

18. Slade, P. D., Owens, R. G. (1998). A dual process model of perfectionism based on reinforcement theory. Behavior Modification, 22, (3), 372-391.

19. Stoeber, J., Otto, K. (2006). Positive Conceptions of Perfectionism: Approaches, Evidence, Challenges. Personalitiy and Social Psychology Review, 10, (4), 295-319.

20. Terry-Short, L.A., Owens, R.G., Slade, P.D. Dewey, M.E. (1995). Positive and negative perfectionism. Personality and Individual Differences, 18, (5), 663-668.

\section{VERBINDUNG ZWISCHEN PERFEKTIONISMUS UND DEM ERLEBNIS VON ERGRIFFENHEIT BEI SPORTLERN VON UNTERSCHIEDLICHER ERFOLGSEBENE}

\section{Zusammenfassung:}

Sportler berichten häufig von Erlebnissen absoluter Hingabe und Ergriffenheit, die eine außerordentliche Erfahrung darstellen und einen motivierenden Einfluss ausüben. Motivation ist ein natürliches Produkt unserer essentiellen Wünsche und Bedürfnisse, Ergriffenheit als mentaler Zustand befreit uns von der Angst vor Einschätzung, was eine Motivationskomponente im Ergriffenheitsmodell sein kann. Ziel dieser Untersuchung war es, festzulegen, in welchem Maße Perfektionismus und Ergriffenheit bei Sportlergruppen vertreten sind, ob sie untereinander verbunden sind und, wenn dies der Fall ist, mit welchen soziodemografischen Variablen sie korrelieren. An der Studie nahmen 50 Sportler aus allen Wettbewerbsebenen teil - von Wettbewerben auf lokaler Ebene bis zu Wettbewerben auf internationaler Ebene. Als Instrumente wurden die Multidimensionale Perfektionismus-Skala, ein Fragenbogen über Ergriffenheit, das halbstruktuierte Interview und ein Fragebogen über soziodemografische Merkmale angewendet. Mit Hilfe des Interviews wurden Informationen über Zustände und Emotionen während eines Erlebnisses der Ergriffenheit erfragt, wo 98\% der befragten Sportler aussagten, dass sie sich des Erlebnisses der Ergriffenheit im gegebenen Moment nicht bewusst sind, aber retrospektiv dieses Gefühl zurückrufen können, das für sie die größte und dauerhafteste Trophäe ihres Erfolgs darstellt. Sportler erzielen auf fast allen Ebenen der Multidimensionalen Perfektionismus-Skala Ergebnisse, die in Bezug auf die allgemeine Bevölkerung höher liegen. Ergebnisse der Untersuchung haben gezeigt, dass es keine Verbindung zwischen dem Erlebnis der Ergriffenheit und Perfektionismus gibt, außer wenn es sich um die Verbindung zwischen dem Erlebenis von Ergriffenheit und Besorgtheit wegen Fehlern handelt. In diesem Fall ist die Verbindung negativ. 